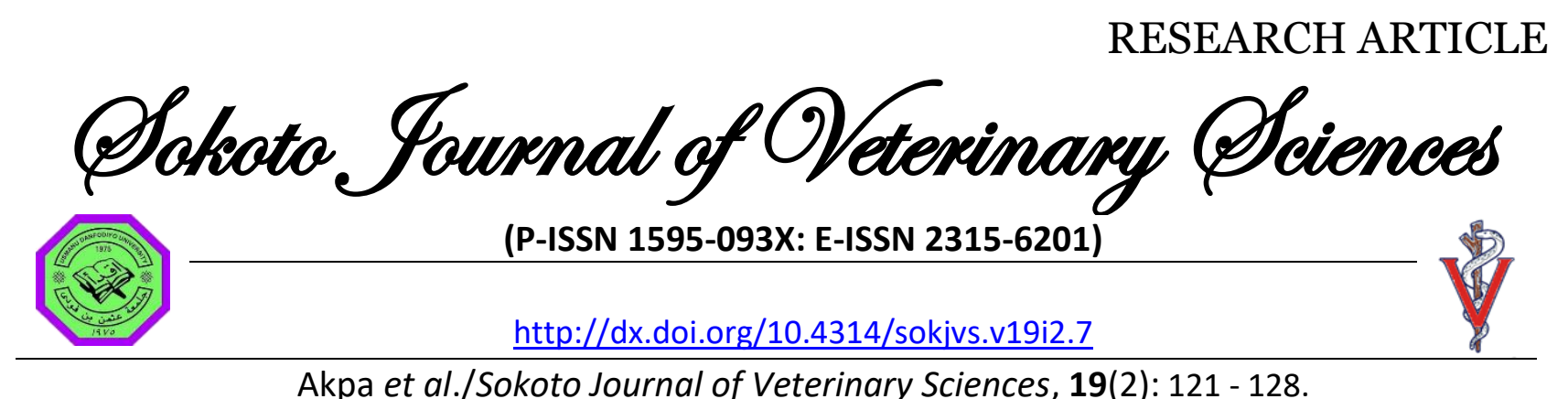

\title{
Effect of treatment with trypanocides on Trypanosoma brucei induced oxidative stress and antioxidant enzyme activities in dogs
}

\author{
PO Akpa ${ }^{1 *}$, PU Umeakuana ${ }^{2}$, TO Nnaji ${ }^{3} \&$ BM Anene $^{4}$ \\ 1. Department of Veterinary Medicine, Faculty of Veterinary Medicine, University of Nigeria, Nsukka, Nigeria \\ 2. Department of Veterinary Medicine, Faculty of Veterinary Medicine, University of Abuja, Abuja, Nigeria \\ 3. Department of Veterinary Surgery, Faculty of Veterinary Medicine, University of Nigeria, University of \\ Nigeria Nsukka, Nigeria \\ 4. Department of Veterinary Medicine, Faculty of Veterinary Medicine, University of Nigeria, Nsukka
}

*Correspondence: Tel.: +2348033506623; E-mail: polycarp.akpa@unn.edu.ng

\begin{abstract}
Copyright: (C) 2021
Akpa et al. This is an

open-access article

published under the

terms of the Creative

Commons Attribution

License which permits

unrestricted use,

distribution, and

reproduction in any

medium, provided the

original author and source are credited.
\end{abstract}

Publication History: Received: 12-01-2021

Revised: 10-04-2021

Accepted: 21-04-2021

\begin{abstract}
Oxidative stress and alteration of endogenous antioxidant enzymes play roles in the pathophysiological mechanism of trypanosomosis. The oxidative stress marker: malondialdehyde- MDA and antioxidative stress markers: Serum catalase- CAT, Serum Reduced Glutathione -GSH-Rd and Serum Superoxide dismutase- SOD of Nigerian local dogs (NLD) experimentally infected with Trypanosoma brucei were evaluated after treatments with diminazene aceturate (DA) and isometamidium chloride (IMC). Twenty dogs of age 3-4 months were assigned to any of the four groups of five dogs each as follows: 1 = infected and treated with DA $(7.0 \mathrm{mg} / \mathrm{kg}) ; 2$ = uninfected untreated; 3 = infected and untreated; 4 = infected and treated with IMC $(0.5 \mathrm{mg} / \mathrm{kg})$. $\mathrm{DA}$ and IMC cleared the parasites from the blood, following treatment of the dogs. Relapse was recorded in two dogs in group 1 and one dog in group 4 on days 35 and 56 post-infection $(\mathrm{PI})$ respectively. No dog died except one in group 1 . The levels of malondialdehyde- MDA increased significantly by day 7 post-infection in all the infected groups. However, by day 14 post-infection the malondialdehyde levels in group 4 became similar with group 2 . The MDA level in group 1 remained significantly higher than in group 2. As from days $7-14$ post-infection Catalase, Reducedg glutathionend superoxide dismutase levels in the infected groups were significantly lower than group 2. Nevertheless, both trypanocides did not return the levels of CAT, $\mathrm{GSH}$, and SOD to pre-infection values before the termination of the experiment. The findings suggested that the two trypanocides could neither reverse the induced oxidative stress nor normalize the antioxidant capacity of the dogs infected with $T$. brucei.
\end{abstract}




\section{Introduction}

The effects of free radical and oxidative stress on tissues and cells have been leading topic in a significant number of studies in human medicine for over 40 years (Salvador \& HendrqueHendriquwes, 2004). More recently, this subject has been gaining ground in veterinary medicine and there are many possibilities for research on the correlation of oxidative stress to diseases. It is a vast field yet to be explored in veterinary sciences.

There are currently lines of scientific evidence showing that many diseases are related to oxidative stress caused by reactive oxygen species (ROS) or reactive nitrogen species (RNS). The most severe damages are the ones affecting the DNA or RNA of the cells. Oxidative stress and alteration of endogenous antioxidant enzymes play roles in the pathophysiological mechanism of trypanosomosis.

Oxidative stress is detected through malondialdehyde (MDA) and isoprostane quantification in addition to the determination of the concentrations of antioxidant agents such as vitamin $\mathrm{E}$ and glutathione peroxidase (Winter et al., 2009). Some diseases of dogs that are related to oxidative stress and antioxidative stress marker quantifications include canine lymphoma, mammary tumors (Szuzzubial et al., 2004; Neto et al., 2005; Ascar et al., 2009; Galvao, 2009), kidney disease and canine cardiopathies (Freeman et al., 2005). Infectious conditions associated with oxidative stress in dogs include cutaneous conditions such as demodicosis (Romanucci et al., 2011). In reproduction, oxidative stress has been associated with ovariohysterectomy.

Few studies have associated oxidative stress with canine trypanosomosis (Omobowale et al., 2015), but none have demonstrated the ameliorative effect of diminazene aceturate (DA) or isometamidium chloride (IMC) on the oxidative stress induced in trypanosomosis. Diminazene aceturate and Isometamidium chlorideare the two commonest drugs used in managing trypanosomosis. Hence, this work was therefore aimed at comparing the ameliorative effect of these two drugs on experimental $T$. brucei induced oxidative stress in dogs.

\section{Materials and Methods}

\section{Experimental animals}

Twenty growing mongrel dogs aged between 3 and 4 months were purchased from Orie Orba market in Nsukka area of Enugu State, Nigeria for the study. They were housed in a fly proof - kennel at the animal house of the Department of Veterinary Parasitology and Entomology of the University of Nigeria, Nsukka. They were acclimatized for four weeks during which they were dewormed and deticked with Ivermectin (ivomec, Merck sharp and dohmes; BV. Hearlem, Holland) at the dose of 0.2 $\mathrm{mg} / \mathrm{kg}$ subcutaneously. They were fed once daily with food procured from the restaurant but supplemented with a meal of garri and okro soup or stew rice cooked with beans prepared by the attendant. Water was provided ad libitum throughout the experiment. They were screened and confirmed negative for trypanosome by buffy coat method (Murray et al., 1977) before the commencement of the experiment. They were also vaccinated against rabies with anti-rabies vaccine and polyvalent vaccine against parvovirus, leptospirosis, canine distemper, infection canine hepatitis diseases using DHLPP vaccine (Forte Dodge Company USA). They were tagged for identification.

\section{Experimental design}

They were assigned into four (4) groups of 5 dogs each as follows:

Group 1: infected, treated with DA $(7.0 \mathrm{mg} / \mathrm{kg})$ Group 2: uninfected, untreated (negative control) Group 3: infected, untreated (positive control) Group 4: infected, treated with IMC $(0.5 \mathrm{mg} / \mathrm{kg})$. Treatment was scheduled to commence when all the dogs are parasitaemic.

\section{Trypanosome infection}

The Trypanosoma brucei used in this study was obtained from Nigerian Institute of Trypanosomiasis Research (NITR) Vom, Plateau State Nigeria. The parasites were maintained in rats before infection of the experimental animals intraperitoneally (i.p) at $10^{6}$ trypanosomes/ml of saline diluted infected blood. The number of parasites was estimated using the rapid matching method of Herbert and Lumsden (1976).

\section{Serum collection}

Four (4) $\mathrm{mL}$ of whole blood was put into clean tubes and allowed to stay for some time to enhance serum yield. The serum was decanted and centrifuged at $2000 \mathrm{rpm}$ for 10 minutes to separate the sera from the cells. The clear serum was used to assay for the oxidative stress and antioxidant markers.

\section{Drug administration}

Diminazene aceturate (Veriben CEVA SANTE ANIMALS, CEDEX France), reconstituted by dissolving 
$1.05 \mathrm{~g}$ of the drug per sachet in $12.5 \mathrm{~mL}$ of sterile water to make and $7.0 \mathrm{mg} / \mathrm{kg}$ was administered to the dogs.

Isometamidium chloride (TrypanidiumSamorinmerial, Lyon France). Reconstituted by dissolving $1 \mathrm{~g}$ of the sachet in $50 \mathrm{ml}$ of sterile water and $0.5 \mathrm{mg} / \mathrm{kg}$ was given to the dogs.

\section{Estimation of parasitaemia}

The parasitaemia level was estimated by the rapid matching method as described by Herbert and Lumsden (1976).

\section{Determination of malondialdehyde:}

Serum malondialdehyde level, a product of lipid peroxidation, was measured based on the method of Stocks \& Dormandy (1971).

Determination of (Serum Catalase-(CAT), Serum Superoxide Dismutase-(SOD), Serum Reduced Glutathione-(GSH-Rd)

The serum catalase activities were determined according to the method described by Goth (1991). A serum superoxide dismutase activity was determined according to the method developed by Misra \& Fridovich (1972). Serum reduced glutathione activities was determined according to the method described by Moron et al. (1979).

Handling of experimental animals during the study Manuscript complied with current animal welfare and ethical guidelines. Of University of Nigeria Nsukka, Faculty of Veterinary Institutional Animal Care and Use Committee. Reference No. FVM-UNNIACUC-2019-1131.

\section{Statistical Analysis}

Data generated were presented as means with standard deviation. The data was subjected to analysis of variance (ANOVA) and the means separated using Duncan's multiple range tests. Means were considered significant at $\mathrm{P}<0.05$.

\section{Results}

\section{Parasitaemia/clinical manifestation}

During the course of infection, clinical signs of dullness, depression, pale mucous membrane, ocular discharges and corneal opacity were observed in the infected untreated (group 3) until the dogs died before the termination of the experiment after showing signs of staggering and aggression. These clinical signs in the treated groups (groups 1 and 4) gradually disappeared following treatment with the trypanocides. The treated groups never showed any sign of the central nervous system. The signs of depression and anorexia were observed again in three dogs in group 1 (DA treated) following a relapse infection.

The Trypanosoma brucei, infected dogs (groups 1, 3, and 4) were positive for T. brucei by day 6-7 postinfection (PI). Treatment for groups 1 and 4 commenced by day 7 post-infectionhen all the infected dogs became parasitaemic. The treated dogs (groups 1 and 4) became a parasitaemic by day 14 post-infection. The parasitaemia was progressive in the untreated control (group 3). By day 28 postinfection 4 members of group 3 died and they all died by day 56 post-infection. By day 35 postinfection relapse infection occurred in two members of group 1 dog (Diminazene aceturate- DA treated), and by day 63 post-infection one member of group 1 (DA treated) died. Relapse of infection also occurred in one member of group 4(IMC treated) by day $56 \mathrm{PI}$. No mortality was recorded in this group till the termination of the experiment (Table 1).

The infection caused a significant increase $(P<0.05)$ in the concentration of serum malondialdehyde when compared to the normal control by day 7 postinfection. The isometamidium chloride treated group became similar with the normal control starting from day 28 unlike the diminazene aceturate treated group. The infected untreated group remained significantly higher $(P<0.05)$ than the normal control and beyond (Table2).

Following infection, the Serum Catalase of the infected groups lowered significantly $(P<0.05)$ when compared with the normal control by day 7 postinfection. From day 14PI the IMC treated group became similar with the normal control except from day 49 post-infection unlike the diminazene aceturate treated and infected and infected untreated that were significantly $\operatorname{lower}(P<0.05)$ till the end of the experiment (Table3).

Infection caused a significant decrease $(P<0.05)$ in the superoxide dismutase by day $7 \mathrm{PI}$. The decrease was progressive in the infected untreated group. On days 14 and 21, SOD was similar in both the isometamidium chloride-treated and diminazene aceturate- treated groups. It was also similar in the isometamidium chloride-treated group from day days $28-42$ and subsequently decreased until the end of the study. The diminazene aceturate treated group was significantly lower however, by day 28 post-infection to the end of the study than the normal control group. There was also a progressive 
Table 1: The parasitaemia of Trypanosoma brucei infected dog groups treated with either $7 \mathrm{mg} / \mathrm{kg}$ Diminazene aceturate or $0.5 \mathrm{mg} / \mathrm{kg}$ Isometamidium chloride

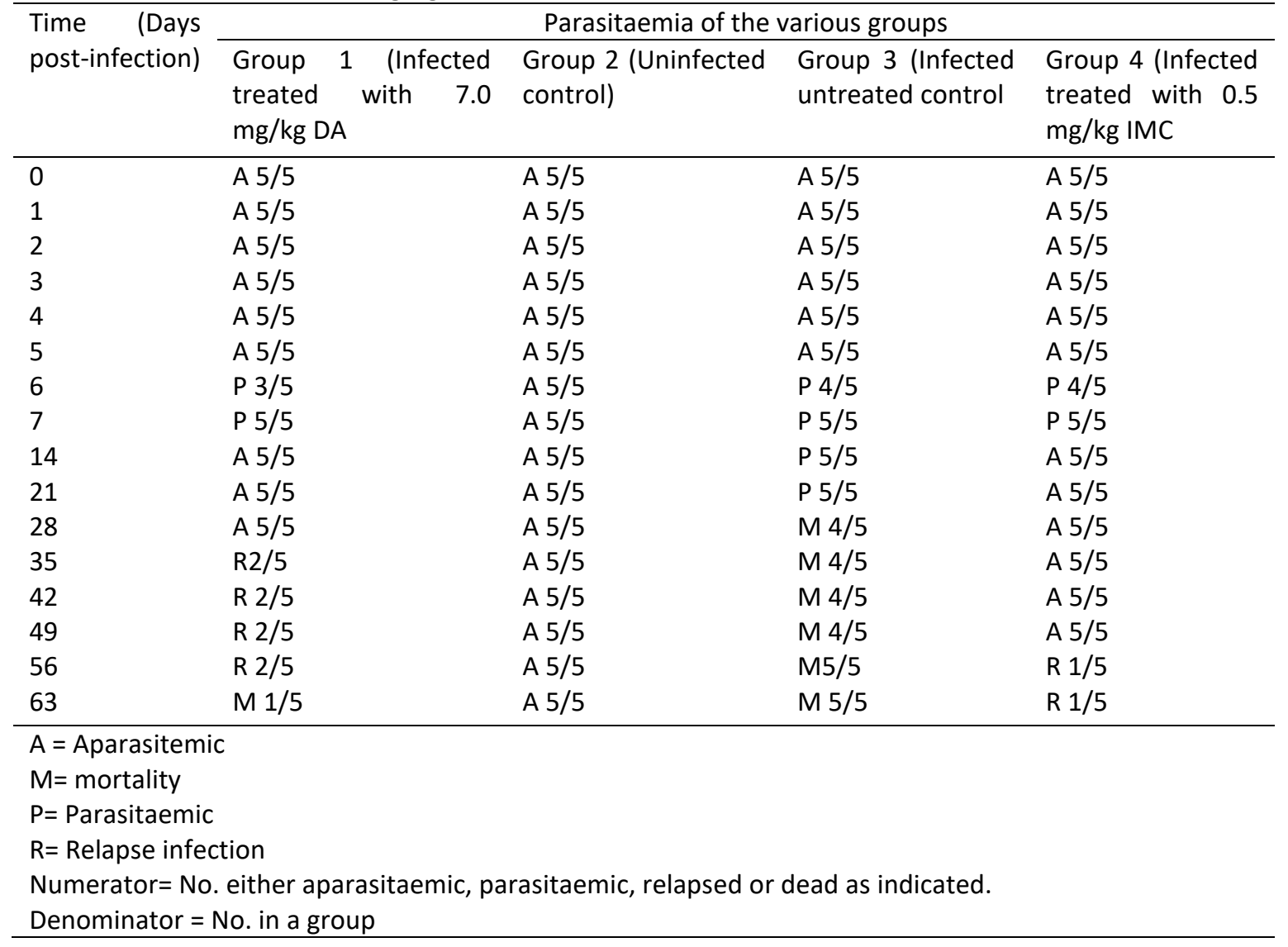

Table 2: The weekly mean serum malondialdehyde $(\mathrm{nmol} / \mathrm{ml})$ of Trypanosoma brucei infected dog groups treated with either diminazene aceturate or isometamidium chloride

\begin{tabular}{|c|c|c|c|c|}
\hline \multirow{2}{*}{$\begin{array}{l}\text { Time } \\
\text { (days) }\end{array}$} & \multicolumn{4}{|c|}{ Mean serum malondialdehyde (MDA)- nmol with standard error in bracket } \\
\hline & $\begin{array}{l}\text { Group } 1 \text { Infected } \\
\text { and treated with } \\
7.0 \mathrm{mg} / \mathrm{kg} \mathrm{DA}\end{array}$ & $\begin{array}{l}\text { Group } 2 \text { Uninfected, } \\
\text { untreated (negative } \\
\text { control) }\end{array}$ & $\begin{array}{l}\text { Group } 3 \text { Infected, } \\
\text { untreated } \\
\text { (positive control) }\end{array}$ & $\begin{array}{l}\text { Group } 4 \text { Infected } \\
\text { and treated with } \\
0.5 \mathrm{mg} / \mathrm{kg} \mathrm{IMC}\end{array}$ \\
\hline 0 & $0.51(0.15)$ & $0.62(0.09)$ & $0.54(0.2)$ & $0.52(0.08)$ \\
\hline 7 & $0.96^{\mathrm{a}}(0.15$ & $0.53^{\mathrm{a}}(0.15)$ & $0.87^{b}(0.10)$ & $0.91^{\mathrm{a}}(0.14)$ \\
\hline 14 & $0.77^{\mathrm{a}}(0.14)$ & $0.56^{a}(0.11)$ & $1.16^{\mathrm{b}}(0.27)$ & $0.66^{\mathrm{a}}(0.22)$ \\
\hline 21 & $0.82^{\mathrm{a}}(0.16)$ & $0.54^{\mathrm{a}}(0.14)$ & $0.99^{b}(0.43)$ & $0.75^{\mathrm{a}}(0.50)$ \\
\hline 28 & $0.95^{\mathrm{b}}(0.22)$ & $0.67^{\mathrm{a}}(0.05)$ & 0.76 & $0.57^{\mathrm{a}}(0.26)$ \\
\hline 35 & $1.18^{\mathrm{b}}(.23) \mathrm{R}$ & $0.64^{\mathrm{a}}(0.09)$ & 0.99 & $0.65^{\mathrm{a}}(0.41)$ \\
\hline 42 & $1.29^{\mathrm{b}}(0.15)$ & $0.56^{\mathrm{a}}(0.11)$ & 1.19 & $0.93^{\mathrm{ab}}(0.46)$ \\
\hline 49 & $1.16^{\mathrm{b}}(0.16)$ & $0.44^{\mathrm{a}}(0.07)$ & 1.30 & $0.66^{\mathrm{a}}(0.38)$ \\
\hline 56 & $1.07^{\mathrm{a}}(0.39)$ & $0.47^{b}(0.06)$ & - & $1.08^{\mathrm{a}}(0.59) \mathrm{R}$ \\
\hline 63 & $1.12^{\mathrm{a}}(0.36)$ & $0.51^{\mathrm{b}}(0.16)$ & - & $1.41^{\mathrm{a}}(0.42)$ \\
\hline
\end{tabular}

decrease in the diminazene aceturate-treated group from day 28 until the end of the study. However, from day 28 post-infection to the end of the diminazene aceturate treated group. The diminazene aceturate treated group was significantly lower than the normal control group. From days 28 -42 , superoxide dismutase in the isometamidium chloride-treated group did not differ from the control but became significantly lower thereafter $(P<0.05)$ till the end of the study. (Table 4$)$. 
Table 3: The weekly serum catalase (ku/L) of Trypanosoma brucei infected dog groups treated with either diminazene aceturate or isometamidium chloride

\begin{tabular}{|c|c|c|c|c|}
\hline \multirow[t]{2}{*}{ Time (days) } & \multicolumn{4}{|c|}{ Mean serum catalase (CAT)- ku/L with standard error in bracket } \\
\hline & $\begin{array}{l}\text { Group } 1 \text { (Infected } \\
\text { and treated with } \\
7.0 \mathrm{mg} / \mathrm{kg} \mathrm{DA}\end{array}$ & $\begin{array}{l}\text { Group } 2 \text { (Uninfected, } \\
\text { untreated (negative } \\
\text { control) }\end{array}$ & $\begin{array}{ll}\text { Group } 3 & \text { Infected, } \\
\text { untreated } & \text { (positive } \\
\text { control) } & \end{array}$ & $\begin{array}{l}\text { Group } 4 \text { Infected } \\
\text { and treated with } \\
0.5 \mathrm{mg} / \mathrm{kg} \mathrm{IMC}\end{array}$ \\
\hline 0 & 47.04 (10.54) & $43.34(6.71)$ & $48.78(4.38)$ & $50.84(10.05)$ \\
\hline 7 & $27.44^{\mathrm{a}}(6.90)$ & $45.32^{b}(6.50)$ & $29.06^{\mathrm{a}}(2.81)$ & $32.04^{\mathrm{a}}(2.29)$ \\
\hline 14 & $32.66^{\mathrm{a}}(10.02)$ & $50.12^{\mathrm{b}}(7.49)$ & $24.28^{\mathrm{a}}(8.95)$ & $48.40^{\mathrm{b}}(3.57)$ \\
\hline 21 & $34.30^{\mathrm{a}}(6.85)$ & $48.64^{\mathrm{b}}(9.12)$ & $32.73^{\mathrm{a}}(14.36)$ & $41.34^{\mathrm{ab}}(7.51)$ \\
\hline 28 & $30.00^{\mathrm{b}}(7.47)$ & $47.26^{\mathrm{a}}(9.75)$ & 43.3 & $44.98(5.96)$ \\
\hline 35 & $28.50^{\mathrm{a}}(3.75) \mathrm{R}$ & $49.04(7.43)$ & 30.2 & $40.78^{b}(10.14)$ \\
\hline 42 & $23.24^{\mathrm{a}}(6.52)$ & $45.82^{b}(5.12)$ & 33.7 & $36.12^{b}(10.50)$ \\
\hline 49 & $20.56^{\mathrm{a}}(6.68)$ & $46.23^{\mathrm{c}}(4.51)$ & 30.61 & $33.73^{b}(10.75)$ \\
\hline 56 & $18.04^{\mathrm{a}}(6.84)$ & $46.26^{\mathrm{b}}(5.63)$ & - & $31.04^{\mathrm{a}}(11.14) \mathrm{R}$ \\
\hline 63 & $19.73^{a}(12.76)$ & $49.40^{C}(3.56)$ & - & $28.30^{\mathrm{b}}(11.04)$ \\
\hline
\end{tabular}

Table 4: The weekly serum superoxide dismutase (SOD) of Trypanosoma brucei infected dog group treated with either diminazene aceturate or isometamidium chloride

\begin{tabular}{|c|c|c|c|c|}
\hline \multirow[t]{2}{*}{ Time (days) } & \multicolumn{4}{|c|}{ Mean serum superoxide dismutase (SOD)- $\mu / \mathrm{ml}$ with standard error in bracket } \\
\hline & $\begin{array}{l}\text { Group } 1 \text { Infected, } \\
\text { treated with } 7.0 \\
\mathrm{mg} / \mathrm{kg} \text { DA }\end{array}$ & $\begin{array}{l}\text { Group } 2 \text { Uninfected, } \\
\text { untreated (negative } \\
\text { control) }\end{array}$ & $\begin{array}{l}\text { Group } 3 \text { Infected, } \\
\text { untreated (positive } \\
\text { control) }\end{array}$ & $\begin{array}{l}\text { Group } 4 \text { Infected and } \\
\text { treated with } 0.5 \\
\mathrm{mg} / \mathrm{kg} \mathrm{IMC}\end{array}$ \\
\hline 0 & $5.19(1.05)$ & $4.64(0.51)$ & $4.96(0.92)$ & $5.27(0.97)$ \\
\hline 7 & $3.78^{\mathrm{a}}(0.46)$ & $4.82^{b}(0.28)$ & $3.43^{\mathrm{a}}(0.85)$ & $3.36^{\mathrm{a}}(1.15)$ \\
\hline 14 & $4.62^{b}(0.83)$ & $5.01^{\mathrm{b}}(0.31)$ & $2.49^{\mathrm{a}}(0.94)$ & $4.35^{\mathrm{b}}(0.55)$ \\
\hline 21 & $5.06^{b}(028)$ & $4.47^{\mathrm{ab}}(0.89)$ & $3.34^{\mathrm{a}}(2.14)$ & $4.58^{\mathrm{ab}}(0.56)$ \\
\hline 28 & $3.66^{\mathrm{a}}(0.45)$ & $5.03^{b}(0.70)$ & 3.22 & $5.30^{\mathrm{b}}(1.03)$ \\
\hline 35 & $3.96^{\mathrm{a}} \mathrm{R}$ & $5.01^{\mathrm{ab}}(0.63)$ & 3.31 & $5.40^{\mathrm{b}}(1.22)$ \\
\hline 42 & $2.62^{\mathrm{a}}$ & $3.77^{\mathrm{b}}(0.49)$ & 2.77 & $4.21^{b}(1.59)$ \\
\hline 49 & $2.39^{\mathrm{a}}$ & $4.81^{\mathrm{b}}(0.63)$ & 1.95 & $2.85^{\mathrm{a}}(0.57) \mathrm{R}$ \\
\hline 56 & $1.60^{\mathrm{a}}$ & $4.87^{b}(0.62)$ & - & $1.47^{\mathrm{a}}(0.50)$ \\
\hline 63 & $2.07^{\mathrm{a}}$ & $7.60^{\mathrm{ab}}(0.45)$ & - & $3.41^{\mathrm{a}}(0.65)$ \\
\hline
\end{tabular}

ab Different superscripts in a row indicate a significant difference between the group means $(P<0.05) ; R=$ Relapse

Infection again caused a significant reduction $(P<0.05)$ in the serum reduced glutathione in the infected untreated group when compared with the normal control by day 14 post-infection. From day $28 \mathrm{PI}$ the infected and treated groups became also significantly lower $(P<0.05)$ than the normal control group and beyond (Table 5 ).

\section{Discussion}

Infection caused a significant increase in the serum level of malondialdehyde, a marker of oxidative stress. This is suggesting that trypanosomosis caused by Trypanosoma brucei induces oxidative stress. This agrees with the work of Kobo et al. (2014) who got the same result in $T$. brucei infected Wistar rats.
Similarly, Eze et al. (2008); Eghiaruwa (2012) also got the same result in rats.

The activities of catalase, reduced glutathione, superoxide dismutase were significantly decreased by the infection. This agrees with the works of Eghianruwa (2012) in T. brucei infected rats, and Omobowale et al. (2015) in T. brucei infected dogs treated with Azadirachta indica. These enzymes are antioxidants naturally produced in cells to neutralize the effect of oxidative stress.

Oxidation can only cause cell necrosis when tissue oxidation overwhelms the effect of antioxidation. The depletion of the antioxidation markers is an indication that $T$. brucei infection caused lipid peroxidation which was manifested in elevated levels of malondialdehyde recorded in the study. 
Table 5: The serum glutathione $(\mathrm{M} \pm \mathrm{SEM})(\mathrm{nmol} / \mathrm{ml})$ of Trypanosoma brucei infected dog groups treated with either diminazene aceturate or isometamidium chloride

\begin{tabular}{|c|c|c|c|c|c|}
\hline \multirow{2}{*}{ Time (days) } & & \multirow[b]{2}{*}{$\begin{array}{l}\text { Group } 2 \text { (Uninfected, } \\
\text { untreated (negative } \\
\text { control) }\end{array}$} & \multirow[b]{2}{*}{$\begin{array}{lr}\text { Group } 3 & \text { (Infected, } \\
\text { untreated } & \text { (positive } \\
\text { control) } & \end{array}$} & \multirow[b]{2}{*}{$\begin{array}{l}\text { Group } 4 \text { (Infected, } \\
\text { treated with } 0.5 \\
\mathrm{mg} / \mathrm{kg} \text { IMC) }\end{array}$} \\
\hline & $\begin{array}{l}\text { Group } \\
\text { treated } \\
\mathrm{mg} / \mathrm{kg} \mathrm{DA}\end{array}$ & $\begin{array}{l}\text { 1(Infected, } \\
\text { with } 7.0\end{array}$ & & & \\
\hline 0 & $7.46(2.18)$ & & $6.52(1.56)$ & $7.26(2.83)$ & $6.04(1.21)$ \\
\hline 7 & $4.87(1.51)$ & & 6.45 (0.99) & $5.73(1.73)$ & $5.36(0.72)$ \\
\hline 14 & $4.97^{\mathrm{ab}}(1.37$ & & $6.84^{\mathrm{b}}(1.78)$ & $3.65^{\mathrm{a}}(2.06)$ & $5.32^{\mathrm{ab}}(1.53)$ \\
\hline 21 & $4.56(1.26)$ & & $6.50(2.19)$ & 4.55 (2.69) & $6.37(4.37)$ \\
\hline 28 & $5.19^{a}(1.30)$ & & $7.35^{b}(0.89)$ & 8.83 & $4.64^{\mathrm{a}}(1.38)$ \\
\hline $35 \mathrm{R}$ & $4.90^{\mathrm{a}}(1.08)$ & & $8.03^{b}(1.11)$ & 7.47 & $4.75^{a}(1.23)$ \\
\hline 42 & $4.53^{\mathrm{a}}(1.17)$ & & $7.62^{b}(0.53)$ & 4.49 & $5.04^{\mathrm{a}}(1.31)$ \\
\hline 49 & $3.69^{a}(0.98)$ & & $7.69^{b}(0.57)$ & 3.00 & $4.03^{a}(1.02)$ \\
\hline 56 & $2.81^{\mathrm{a}}(1.51)$ & & $7.65^{b}(0.46)$ & - & $3.54^{\mathrm{a}}(0.57) \mathrm{R}$ \\
\hline 63 & $0.80^{\mathrm{a}}(0.14)$ & & $4.81^{b}(0.58)$ & - & $1.29^{\mathrm{a}}(0.55)$ \\
\hline
\end{tabular}

ab Different superscripts in a row indicate significant difference between group means $(P<0.05) ; R=$ Relapse

The trypanocides diminazene aceturate and isometamidium chloride did not satisfactorily reverse this trend. This was similarly observed by Omobowale et al. (2015). The results of this study show that experimental infection of dogs with Trypanosoma brucei through the intraperitoneal route was established between six to seven days post-infection (PI). The prepatent period of $T$. brucei is known to be variable. However, it agrees with the report of Anene et al. (1989), who observed the prepatent period for canine trypanosomosis caused by $T$. brucei to be between four to eight days. It contrasted with the work of Sewell et al. (1990) that recorded a prepatent period of $3-4$ days in dogs. The variations in the prepatent period may be due to strain of the $T$. brucei stock used or due to inherent quality of the infected dogs. In this experiment, one can deduce that canine trypanosomosis caused by $T$. brucei ran an acute course in dogs, as opposed to chronic disease course due to $T$. congolense (Amole et al., 1982; Mario et al., 1997). The death of the dogs in the infected untreated control dogs within 28 days $\mathrm{PI}$ can be due to the parasite's immunosuppressive effects, hence not allowing the dogs enough time to produce sufficient antibodies to fight the invading parasite.

The clinical signs of corneal opacity, pale mucosae, staggering movement, ocular discharges, weakness and lethargy were consistent with findings of previous researchers (Ezeh et al., 2009; Umeakuana et al., 2019).

The trypanocides cleared the parasitaemia following treatment by day $14 \mathrm{PI}$ indicating that diminazene aceturate (DA) and isometamidium chloride (IMC) were efficacious in the treatment of $T$. brucei in dogs. However, the trypanocides (diminazene aceturate and isometamidium chloride) did not satisfactorily reverse the antioxidative stress and antioxidant markers to its normal values. This could be due to the relapse infection observed post treatment with the trypanocides. The relapse occurred much earlier in the DA-treated than in IMC treated group hence the seemingly better result recorded among the IMC treated group.

Relapses after treatment have been suggested to be due to drugs resistance and due to invasion of brain tissues by the parasites where the trypanocides' molecule cannot reach (Jennings et al; 1980 Barrett, 2001). In the brain, the parasites are protected by the blood-brain barrier which is impervious to the large molecules of the trypanocides. Subsequently, the parasites re-enter the vascular system when the effect of the drugs in the blood stream would have waned. It was thus concluded that the diminazene aceturate and isometamidium chloride though effective in clearing the parasites from the blood after administration could not satisfactorily ameliorate the oxidative stress induced by $T$. brucei infection in dogs.

\section{Acknowledgements}

We thank Tertiary Education Trust Fund (TET Fund) for sponsoring this study under the Institution Based Research (IBR) intervention, and the Director, Nigerian Institute for Trypanosomiasis Research (NITR), Vom, Plateau State, Nigeria for the supply of the Trypanosoma brucei used in this study.

\section{Conflicts of Interest}

The authors declare no conflict of interest. 


\section{References}

Amole BO, Clarkson JR \& Shear HL (1982). Pathogenesis of animal anaemia in Trypanosoma bruceibrucei infected mice. Infect. Immun., 36(3): 1060-1068.

Anene BM, Chukwu CC \& Anika SM (1989). Immunosuppression and humoral immune response in canine trypanosomiasis. Microbios Letters, 40(157): 37-46.

Ascar TK, Samanoglu B, SamongoluR, Erkal N \& Beskaya A (2009). Changes in oxidative status and trace element levels in dogs with mammary tumours. Acta Veterinaria, 59(4): 405-411.

Barrett MP (2001). A possible veterinary link to drug resistance in human African trypanosomiasis. Lancet, doi.10.1016/s0140-6736(01)05817-2.

Eghianruwa KI (2012). The effect of supplemental antioxidants of vitamin $\mathrm{C}$ and dimethyl sulfoxide on weight gain and survival in Trypanosoma brucei infected rat and diminazene treated rats. Veterinary Archives, 82(5): 519-529.

Eze JI, Anene BM \& Chukwu CC (2008). Determination of serum organ malondialdehyde concentration, a lipid peroxidation index in Trypanosoma brucei infected rat. Comparative Clinical Pathology, doi.10.1007/s00580-008-0722-6

Ezeh IO, Agbo LI, Emehelu CO, Nweze EN, Ezeokonkwo RC \& Onah DN (2009). Berenilresistant Trypanosoma bruce ibrucei infection in hunting dog in Nsukka area, Enugu state, Nigeria. Nigerian Veterinary Journal, 29(4): 34-42.

Freeman LM, Rush JE, Milbury PE \& Blumberge JB. (2005). Antioxidant status and biomarkers of oxidative stress in dogs with congestive heart failure. Journal of Veterinary Internal Medicine, 19(4): 537- 541.

Galvao ALB (2009). Estresseoxidative nos estagiofinais da doencaranalcronicaempequenos animais. Archives of Veterinary Science, 14(3): 178186.

Goth $L$ (1991). A simple method for determination of serum catalase activity and revision of reference range. Clinica Chimica Acta, doi.10.1016/0009-8981(91)90067-m.

Herbert WJ \& Lumsden, WHR (1976). Trypanosoma brucei: A rapid matching for estimating the host's parasitaemia. Experimental Parasitology, 4:0 427-428.
Jenning FW, Urguhart GM, Murray PK \& Miller BM (1980). Berenil and nitroimidazole combinations in the treatment of Trypanosomabrucei infections with central nervous system involvement. International Journal of Parasitology, doi.10.1016/00207519(80)90060-0.

Kobo POPI, Ayo JO, Aluwong T, Zezi AU, Maikai, V \& Ambali SF (2014). Flavonoid mixture amelioriates increase in erythrocyte osmotic fragility and malondialdehyde concentration induced by Trypanosoma brucei infection in Wistars. Research in Veterinary Science, 96(1): 139-42.

Mario L, De la Rue RAS \& Geraldo ADC (1997). Coagulopathy in dogs infected with Trypanosoma evansi. Journal of Clinical Microbiology, doi.10.4067/S071607201997000300005.

Misra HP \& Fridovich I (1972). The role of superoxide anion in the authoxidation of epinephrine and a simple assay for superoxide dismutase. Journal of Biological Chemistry, 247(10): 3170-3175.

Moron MS, Depierre JW \& Mannervik B (1979). Levels of glutathione, glutathione reductase and glutathione S-transferase activities in rat lung and liver. Biochimica et biophysica acta, 582(1): 67-78.

Murray M, Huan CN, Lambert PH \& Gerber H (1977). The Anaemia of African Trypanosomosis. Demonstration of a Haemolytic Factor. International Scientific Council for Trypanosomiasis Research and Control, 15.

Neto F, Silva JC, Fagundes DJ, Percário S, Novo NF, Juliano Y \& Moreira Neto AA (2005). Study of oxidative changes, total antioxidant capacity and nitric oxide in rats submitted to ischemia and reperfusion of hind limbs. Acta. Cirur Brailiera, 20(2): 48-56.

Omobowale TO, Oyagbemi AA, Oyewunmi OA \& Adejumobi OA (2015). Chemopreventive effect of methanolic extract of Azadirachta indica on experimental Trypanosoma brucei induced oxidative stress in dogs. Pharmacognosy Research, 7(3): 249-258.

Romanucci M, Bonggiovanni L, Ruusso A, Capuccini S, Medrelli L, Orddeix L \& Sallda LD (2011). Oxidative stress in the pathogenesis of canine zinc- responsive dermatosis. Veterinary Dermatology, 22(1): 31-38.

Salvador M \& HendrqueHendriquwes JAP (2004). Free radicals and the cellular response to 
oxidative stress. Canoas: EditoraUlbra, p 204.

Sewell MMH \& Brocelesby DW (1990). Handbook on animal diseases in the tropics (London: Bailere Tindall, fourth edition). Pp. 205-217

Stocks J \& Dormandy TL (1971). The authoxidation of human red cell lipids induced by hydrogen peroxide. British Journal of Haematology, doi.10.1111/j.1365-2141.1971.tb00790.x.

Szuzzibial M, Kankofer M, Bochnicarz M \& Lipko J (2004). Oxidative stress parameters in bitches with mammary gland tumours. Journal of Veterinary Medicine and
Physiology, Pathology, Clinical Medicine, 51(7-8): 336- 340.

Umeakuana PU, Gibson W, Ezeokonkwo RC \& Anene BM (2019). Identification of Trypanosoma brucei gambiense in naturally infected dogs in Nigeria. Parasites Vectors, doi.org/10.1186/s13071-019-3680-8

Winter JL, Barber LG, Freeman L, Griessmayr PC, Milbury PE \& Blumberg JB (2009). Antioxidant status and biomarkers of oxidative stress in dogs with lymphoma. Journal of Veterinary Internal Medicine, 23(2): 311-316. 